\author{
자전거 의류 착용실태 조사 \\ 정희경 ${ }^{1)} \cdot$ 이정란 ${ }^{2)}$ \\ 1)부산대학교 의류학과 \\ 2)부산대학교 의류학과/부산대학교 노인생활환경연구소
}

\title{
Actual Wearing Conditions of Bicycle Wear
}

\author{
Hee-Kyeong Jung ${ }^{1)}$ and Jeong-Ran Lee ${ }^{2) \dagger}$ \\ ${ }^{1)}$ Dept. of Clothing \& Textiles, Pusan National University; Pusan, Korea \\ ${ }^{2)}$ Dept. of Clothing \& Textiles/Research Institute of Ecology for the Elderly, Pusan National University; Pusan, Korea
}

\begin{abstract}
This study identifies how people use bicycle wear, complaints about bicycle wear, and functions required for bicycle riding. This survey was conducted with bicycle club members (men and women) in their twenties to sixties who ride bicycles on a regular basis. A total of 373 subjects responded to questionnaires and 326 responses were used for further data analysis. The data was analyzed by descriptive analysis, multiple response analysis, crosstabulation analysis, factor analysis, reliability analysis, and one-way ANOVA. The results are as follow: First, the people surveyed were primarily men, young adults and middle-aged people. They ride bicycles mainly to participate in club activities, to exercise, and to spend their spare time with a well-being trend that focuses on leisure and health. Second, they often utilize bicycle wear when they ride bicycles. They are aware of bicycle wear brands. In addition, a majority have purchased bicycle wear that shows a very high awareness of bicycle wear. Third, as for complaints about bicycle wear worn when riding bicycles, a majority of people answered that the waist part of the top pulls up and they feel sore with the bottom part of the pants when riding bicycles for a long time. They also answered that it is inconvenient to put belongings in both tops and pants. Fourth, there is a high demand for safety-related functions for bicycle riding in regards to the functions required for bicycle wear. In addition, a majority of the members showed a customer awareness of functional bicycle wear and intended to purchase bicycle wear equipped with smart functions.
\end{abstract}

Key words: bicycle wear(자전거 의류), actual wearing condition(착용실태), smart function(스마트 기능)

\section{1. 서 론}

국내 자전거 동호인 인구가 600 만명을 넘어서면서, 자전거 라이딩을 즐기는 연령대가 다양해지고 세분화되었다. 자전거를 이용해 출퇴근하는 이른바 '자출족'의 급증과 더불어 자전거에 대한 관심이 증가하여 국내 자전거 인구는 현재 1000 만명에 이 르고 있다(“Lafuma bicycle”, 2010). 자전거는 에너지 절감의 효과가 있는 친환경 녹색교통수단으로 전용도로 확대실시, 4대 강 유역 자전거길 개통 등과 같은 정부 및 산하기관의 정책적 인 지원을 받고 있다. 이와 함께 가계소득 증가, 여가의식의 개 선, 건강에 대한 관심의 고조 등으로 단순한 이동수단이 아닌 레저와 스포츠로서 자전거 관련 산업이 활성화되고 있다. 자전 거 시장은 전 세계적으로 약 8 조 5000 억원 규모이며, 국내 자 전거 시장 규모는 약 2000 억원으로 연평균 $18 \%$ 씩 성장하고 있으며(Jeong, 2010), 자전거 의류 및 관련 용품의 시장 확대

$\dagger$ Corresponding author; Jeong-Ran Lee

Tel. +82-51-510-2841, Fax. +82-51-583-5975

E-mail: ljrj@pusan.ac.kr
에 따라 성장이 가속화될 것으로 기대된다.

자전거 타기는 라이딩 시 발목과 무릎에 부담을 주지 않고, 안장과 어깨에 체중이 고루 분산되어 신체의 특정 부위에 무리 를 주지 않는 운동으로서, 점차 자전거 이용이 증가하는 추세 임에도 불구하고 현재까지 자전거 의류는 개념이 정확하게 정 립되어 있지 않고, 아웃도어 의류와 혼재되어 사용되고 있는 실 정이다. 자전거 의류는 자전거 주행능력을 향상시키고 소속된 단체의 상징성을 부각시키는 의복이다. 주5일제 전면시행으로 인한 라이프스타일 및 소비패턴이 변화된 소비자들은 다양한 기 능을 가진 자전거 의류를 원하고 있으며, 관련용품도 보다 전문 화된 제품을 추구하는 경향이 짙어지고 있다(Cho, 2012). 또한 이들은 의복을 통해 신체를 보호하는 것뿐만 아니라 자신의 개 성을 표현함으로써 심리적 만족감을 얻으려 하고 있다. 그러나 현재 국내에서 판매되고 있는 자전거 의류의 경우 대부분이 수 입제품으로 가격이 매우 높은 편임에도 불구하고 디자인, 소재, 치수 및 동작 적합성의 불만이 높아 국내 소비자를 고려한 자 전거 의류에 대한 연구의 필요성이 대두되고 있다(Kim, 2010). 자전거 의류에 대한 선행연구를 살펴보면, 자전거 주행 시 
의복의 착용현황과 의복의 동작적응성 관련 불만요인에 관한 연구(Kim, 2010), 자전거 의류 남성 착용자를 중심으로 자전거 의류의 만족도와 착용감에 대한 연구(Lee \& Suh, 2008)가 있 으며, 여성 사이클 선수들의 체형특성과 이상적인 패턴개발에 관한 연구(Choi, 2004) 등이 이루어졌다. 하지만 아직까지 우리 나라에서는 자전거 의류에 대한 연구가 부족한 실정이며, 소비 자들의 요구에 맞춘 기능성 자전거 의류에 대한 연구는 거의 없는 실정이다. 따라서 본 연구에서는 자전거 의류의 착용실태 를 파악함으로써 소비자의 만족도를 높이며, 전문선수 및 일반 인을 타깃으로 한 신체적합성이 높은 기능성 자전거 의류 개발 에 필요한 기초자료를 제시하고자 한다.

\section{2. 자전거 의류 개발 현황}

\section{1. 자전거 이용 확대}

자전거는 교통 혼잡을 피하고, 공기오염물질의 방출과 온실 가스를 줄이는 데에 효과가 있는 반면, 인간의 물리적인 활동 을 증가시키는 장점이 부각되면서, 대체 교통수단으로써 점점 더 많이 선택되어지고 장려되고 있다. 그 예로, 서울시에서 에 너지절약과 시민의 건강증진 등의 목적을 가지고 2007년에 자 전거이용활성화에 관한 조례를 제정하여 공포하였으며, 2012년 까지 가변차로나 자전거 중앙차로 등을 이용해 $207 \mathrm{~km}$ 에 이르 는 자전거 전용도로를 조성할 계획을 하고 있다 $(\mathrm{Kim}$ et al., 2009). 또한, 국토해양부와 행정안전부에서는 친환경 녹색교통 수단인 자전거 이용에 대하여 국민들의 관심과 요구에 부응하 고, 자전거를 이용하는 사람들에게 보다 안전하고 편리한 자전 거생활 환경을 제공하기 위하여 2010년 7월에 자전거 이용시 설 설치 및 관리지침을 제정하였다.

서울시의 자전거도로 역시 점차 확장돼가고 있는 추세이다. 지난 1996년에는 $163.8 \mathrm{~km}$ 에 불과하였으나, 2001년에는 482 $\mathrm{km}, 2010$ 년 말까지 $860 \mathrm{~km}$, 현재는 자전거 전용도로와 자전 거-보행자 겸용도로를 합쳐 $900 \mathrm{~km}$ 를 넘어서 곧 총연장 1,000 $\mathrm{km}$ 를 눈앞에 두고 있다. 이에 따른 자전거 도로율은 전체도로 대비 2001년 6.10\%에서 2010년 10.4\%로 증가했다. 서울시는 도심, 생활권역, 한강 등 서울시 전역을 대상으로 자전거도로 건설, 편의시설 설치, 기타 자전거 이용활성화 사업을 지속적으 로 추진하고 있다(Park, 2012).

국내 자전거 시장은 IMF, 금융위기 때를 제외하고 매년 $18 \%$ 규모의 안정적인 성장을 하고 있다. 그러나 올해부터 4 대 강 유역 자전거길 개통에 따른 전용도로 인프라 확충, 레저인 구의 확대, 유가급등, 고가 자전거 판매량 증가 등으로 $30 \%$ 이 상 급성장할 것으로 예상된다(Kim, 2012). 정부는 자전거 인프 라 투자확대를 통해 향후 10 년 내 자전거 교통분담률을 현 $12 \%$ 에서 유럽 수준인 $20 \%$ 까지 끌어올릴 계획이다(Lim, 2012).

자전거는 누구나 쉽게 즐길 수 있고, 체력을 증진시키며, 건 강에도 도움을 준다. 자전거 타기는 관절에 무리를 주지 않는 유산소 운동으로, 페달을 돌릴 때 하체 근육을 많이 사용하므
로 하체가 단련되며, 안장에 앉아 허리를 지지하게 되므로 허 리 근육이 튼튼해진다. 또한 자전거를 타면 전체적으로 칼로리 소비가 많아 체중감량 효과를 얻을 수 있으며, 심폐기능을 강 화하는데도 도움을 주기 때문에 호흡기나 순환기 발달에 효과 가 있고, 혈압이 내려가고 심장박동수도 안정되며, 피로가 낮아 지는 것을 느끼게 되어 스트레스 해소에 도움을 준다(Jeong, 2011). 이러한 자전거 타기의 장점으로 인해 20 30대는 물론 중장년층에게도 인기를 끌고 있으며, 해마다 자전거를 타려는 사람들이 늘고 있다(“Outdoor market”, 2011). 자전거를 이용 하는 사람들이 늘어나면서 각 지자체들은 자전거 이용자들을 적극 배려하는 의미에서 자전거길 보충 및 보수 계획을 연이어 발효하고 있으며, 정부 차원에서도 자전거 이용을 적극 권장하 고 있다. 이와 같은 사회적 분위기 속에서 자전거 전문 의류와 각종 소품을 구매하고, 일상생활 곳곳에서 자전거를 즐기는 사 람들이 점차 증가하고 있는 실정이다.

\section{2. 자전거 의류 매출 증가}

휘발유 가격이 2000 원대를 넘어서는 고유가가 지속되고, 대 중교통 요금이 오른 가운데, 최근 각 온라인 쇼핑몰에서 자전 거 관련 의류 매출이 증가하고 있다. 2011년 9월 17일부터 한 달간 11 번가(www.11st.co.kr)에서는 자전거 관련 의류 매출이 전월대비 $50 \%$ 올랐으며, 전자상거래 사이트 옥션(www.auction. co.kr)에서는 자전거 관련 의류 판매가 $33 \%$ 증가했다("Bicycle Goods", 2011). 또, 옥션이 ‘올해의 히트상품 10선'을 조사한 결과, 자전거 의류는 전년 대비 $35 \%$ 증가, 7 만 건 이상 판매 되어 8위를 차지했다(Shin, 2011). 인터파크(www.intrepark. com)는 2012년 3월 28일부터 4월 3일까지 자전거 카테고리 매출이 전주 동기대비 $30 \%$, 자전거 의류 매출이 $20 \%$ 이상 증 가했으며, $\mathrm{G}$ 마켓(www.gmarket.co.kr)도 같은 기간 자전거 판매 량이 전주 대비 $16 \%$ 증가했고, $\mathrm{TV}$ 홈쇼핑 채널이 운영하는 온 라인몰에서도 자전거 관련 매출이 증가하고 있다(Ryu, 2012).

기능성 자전거 의류는 내구성이 뛰어나고 탄력회복성이 높 은 것이 좋다. 또한 착장 시 생리적인 불편함이 없어야 하고 동작이 편리해야한다(Kim \& Park, 2011). 하의는 신축성이 좋 아 페달을 밟을 때, 바지아랫단 부분이 말려 올라가지 않아야 하며, 땀을 잘 흡수하고 건조하는 흡한, 속건성 소재를 사용해 야 한다. 특히 야외 활동이 주를 이루므로, 직접적인 자외선의 영향을 받지 않도록 자외선 차단효과가 있어야 한다("Bicycle fashion", 2010). 자전거 의류의 사이즈는 신체의 움직임이 많으 므로 편안하게 활동할 수 있도록 사용자의 몸에 꼭 맞게 제작되 어야 하며, 부드러운 재질로 착용감과 신축성이 우수해야 한다. 자전거 의류의 색은 눈에 잘 띄는 색이 좋은데, 이는 패션성 측 면과 함께 밝은 색상과 반사되는 물질이 함유된 옷이 남의 눈에 더 잘 띄기 때문에 안전을 지키는데 도움을 주기 때문이다.

\section{3. 자전거 의류 브랜드}

현재 국내에서 판매되고 있는 자전거 의류는 대부분 수입 브 
랜드로 브랜드의 역사가 오래되어 국내 자전거 동호인과 전문 선수들에게 인지도가 높았으며, 다양한 기능성 소재와 인체공 학적인 패턴이 특징이었다. 자체개발한 흡한-속건 소재인 울트 라센서(Ultrasensor)라는 소재(Lee \& Suh, 2008)를 사용하는 업체가 있었고, 특수 코팅공법을 사용하여 $100 \%$ 방수, 방풍 및 투습 기능을 가진 소재를 사용하는 업체, 스위스 에슐러 원단 과 이태리 TMF사의 패드를 사용하는 업체가 있었다. 라이선스 브랜드의 자전거 의류는 가볍고 얇아서 휴대가 용이하며, 라이 딩 자세에 맞춰서 패턴이 설계되어 있어 기능성면에서 좋은 평 가를 받았으나, 뛰어난 기능성만큼 가격대가 높은 것이 소비자 들의 불만요인이 되고 있었다.

이에 비해 내셔널 자전거 의류 브랜드는 대부분 아웃도어 의 류 시장에서 인지도가 높은 브랜드가 자전거 의류 라인을 런칭 한 경우로, 다양한 제품군과 10 만원 미만의 비교적 저렴한 가 격이 특징이었으나, 기준설정 치수의 제시 방법이 달라 구매 시 소비자들의 선택에 어려움이 있을 것으로 사료되었다.

이밖에 아웃도어 기능성원단으로 유명한 고어텍스(GORE $\mathrm{TEX}$ )에서 만든 자전거 의류 브랜드인 해외구매 대행업체가 있 었는데, 성능과 디자인이 우수하여 유럽 IF디자인 대상을 수상 하기도 하였다. 인체해부학적인 $3 \mathrm{D}$ 재단으로 정확하게 몸에 맞 도록 제작되었으며, 방풍 포켓 처리가 된 잠금 지퍼, 엉덩이를 감싸게 만든 부분, 야간 라이딩을 위한 반사 테이핑 처리 등 디자인 및 기능성에서 매우 높은 평가를 받았다. 하지만, 국내 소비자들은 해외구매대행을 통해서만 의류를 구입할 수 있어 접근성이 어렵고, 가격대가 매우 높아 인지도에 비해 실구매자 의 수는 비교적 적었다.

\section{3. 연구방법}

본 연구에서는 자전거 의류 착용실태와 불편사항 및 자전거 주행 시 요구되는 기능성을 조사하기 위하여 자전거 동호회 회 원 및 자전거를 주기적으로 이용하면서 구매력이 있는 20대 60 대 남녀를 대상으로 설문조사를 진행하였다. 조사기간은 2012 년 4월부터 5월까지였다. 총 373부를 배부하여 354부가 회수 되었으며, 불완전한 응답을 한 28 부를 제외하고 총 326 부를 자 료 분석에 사용하였다. 조사내용은 응답자의 일반적 속성, 자전 거 이용 시 착용하는 의복 이용 현황, 자전거 주행 시 착용한 의복의 불편사항, 자전거 의류에 필요한 기능 등이다. 설문조사 결과를 통해 수집된 자료들을 SPSS 18.0 ver 프로그램을 사용 하여 통계 처리하였으며, 기술통계, 다중응답분석, 요인분석, 신 뢰도분석, 상관분석, 교차분석, 분산분석을 실시하였다.

\section{4. 결과 및 고찰}

\section{1. 조사대상자의 일반적 사항}

조사 대상자의 일반적 사항은 Table 1과 같다. 본 연구의 설 문 대상자 326 명 중 남자가 208명(63.8\%), 여자가 118 명
Table 1. Characteristics of respondents $(\mathrm{N}=326)$

\begin{tabular}{|c|c|c|c|}
\hline \multicolumn{2}{|c|}{ Characteristics } & $\mathrm{N}$ & $\%$ \\
\hline \multirow{3}{*}{ Gender } & Male & 208 & 63.8 \\
\hline & Female & 118 & 36.2 \\
\hline & Total & 326 & 100.0 \\
\hline \multirow{6}{*}{ Age } & 20 29 years old & 77 & 23.6 \\
\hline & $30 \sim 39$ years old & 80 & 24.5 \\
\hline & 40 49 years old & 49 & 15.0 \\
\hline & 50 59 years old & 85 & 26.1 \\
\hline & over 60 years old & 35 & 10.7 \\
\hline & Total & 326 & 100.0 \\
\hline \multirow{5}{*}{ Career } & under 1 year & 53 & 16.3 \\
\hline & $1 \sim 3$ years & 117 & 35.9 \\
\hline & $3 \sim 5$ years & 72 & 22.1 \\
\hline & over 5 years & 84 & 25.8 \\
\hline & Total & 326 & 100.0 \\
\hline \multirow{5}{*}{$\begin{array}{c}\text { Time of riding bicycle } \\
\text { for a weeks }\end{array}$} & under 3 hours & 76 & 23.3 \\
\hline & $3 \sim 6$ hours & 112 & 34.4 \\
\hline & $6 \sim 12$ hours & 76 & 23.3 \\
\hline & over 12 hours & 62 & 19.0 \\
\hline & Total & 326 & 100.0 \\
\hline \multirow{4}{*}{ Ability of riding bicycle } & Beginner & 81 & 24.8 \\
\hline & Intermediate & 211 & 64.7 \\
\hline & Upper & 34 & 10.4 \\
\hline & Total & 326 & 100.0 \\
\hline \multirow{7}{*}{$\begin{array}{l}\text { Purpose of riding } \\
\text { bicycle }\end{array}$} & Club activities & 133 & 29.2 \\
\hline & Commuting & 55 & 12.1 \\
\hline & Leisure & 93 & 20.4 \\
\hline & Exercise & 122 & 26.8 \\
\hline & Diet & 12 & 2.6 \\
\hline & Stress reduction & 41 & 9.0 \\
\hline & $\begin{array}{l}\text { Total(Multiple } \\
\text { response) }\end{array}$ & 456 & 100.0 \\
\hline
\end{tabular}

Shading indicates the highest percentage

(36.2\%)으로 남자의 비율이 더 높게 나타났다. 연령은 50 대가 85 명 (26.1\%)로 가장 많았으며, 다음으로 30대가 80명 (24.5\%), 20 대가 77 명 $(23.6 \%)$ 순으로 나타나 자전거를 즐기는 연령층이 다양해지고 있으며, 건강에 대한 관심의 증가로 인해 50 대에서 자전거 이용이 특히 두드러지는 것으로 보인다.

자전거를 탄 기간은 1년 이상 3년 미만이 117명(35.9\%)으로 가장 많이 나타났으며, 다음으로 5년 이상이 84명(25.8\%), 3 5 년 미만이 72 명(22.1\%)의 순으로 많이 나타나 자전거를 꾸준히 이용해 오고 있는 것으로 보인다. 일주일 동안 자전거를 타는 시간은 3 6시간이 112 명(34.4\%)으로 가장 많았으며, 3시간 미 만과 6 12시간 이상이 각각 76명(23.3\%)으로 나타났다. 조사 대상자 중 211 명 $(64.7 \%)$ 이 자신의 자전거 실력을 중급이라고 응답하였으며, 자전거를 이용하는 주된 목적은 동호회활동이 133 명(29.2\%)으로 가장 많았다. 다음으로 운동용이 122 명 
(26.8\%), 여가선용이 93명(20.4\%) 순으로 나타나 현대인들은 웰빙 트렌드의 영향으로 자전거를 이용하여 활발하게 동호회 활동에 참여하고, 이를 통해 건강한 여가선용을 즐기는 것으로 파악된다.

\section{2. 자전거 이용 시 착용하는 의복 현황}

자전거 주행 시 착용하는 의복에 대해 살펴보면, 조사대상자 의 208 명 $(63.8 \%)$ 이 자전거 전문 의류를 착용한다고 응답하였 으며, 자전거 의류를 전문으로 생산하는 브랜드를 알고 있다고 답한 응답자는 249 명(76.4\%)이었다. 자전거 전문 의류를 구매 한 경험이 있다고 응답자는 전체의 250 명 $(76.7 \%)$ 로, 자전거 의 류 구매 장소는 자전거 의류 전문매장이 148 명 $(52.3 \%)$ 로 가장 높게 나타났으며, 다음으로 인터넷쇼핑몰이 106명(37.5\%), 해외 구매대행을 이용한다는 응답이 14 명 $(4.9 \%)$ 로 나타났으며, 기타 의견으로 동호회를 통해 공동구매한다는 의견도 다수 있었다. 자전거 주행 시 자전거 의류를 얼마나 자주 착용하는지에 대해 조사한 결과, 항상 착용한다가 199명(79.0\%)으로 가장 높게 나 타났고, 모임이나 강습 시 착용한다가 37 명 $(14.7 \%)$ 으로 나타나 자전거를 이용하는 대부분의 사람들이 자전거 의류에 대해 알 고 있으며, 착용빈도가 높은 것으로 파악된다(Table 2).

자전거 의류 구입 시 선택의 기준이 되는 항목을 10 점 만점 으로 조사한 결과, 기능성이 평균 8.23점으로 가장 높았으며, 그 다음으로는 사이즈가 평균 8.15점, 디자인이 7.94점 순으로 높 았다. 연령대별로 자전거 의류 구입 시 선택의 기준에 차이가 있는지 알아본 결과, 디자인, 가격, 소재, 색상, 사이즈에서 연령 대별로 유의한 차이가 나타났다. 기능성과 브랜드는 연령대별로 유의한 차이는 나지 않았으나, 기능성은 모든 연령대에서 전체 적으로 높은 점수를 차지한 반면, 브랜드는 모든 연령대에서 가 장 낮은 점수를 차지하는 것으로 나타나 기능성은 의복을 선택 할 때 중요한 요인이지만, 브랜드는 그다지 중요하게 생각하지 않는다는 것을 알 수 있었다. 또한 디자인과 가격 항목은 20대 와 30 대에서 특히 중요하게 생각하는 것으로 나타나 자전거 의 류 제작 시 타깃 층을 고려한 디자인설계가 뒷받침되어야 하며, 적절한 가격대가 책정되어야 할 것으로 사료된다(Table 3 ).
Table 2. Wearing condition of bicycle wear $(\mathrm{N}=326)$

\begin{tabular}{|c|c|c|c|}
\hline Category & Detailed item & $\mathrm{N}$ & $\%$ \\
\hline \multirow{3}{*}{ Brand knowledge } & Yes & 249 & 76.4 \\
\hline & No & 77 & 23.6 \\
\hline & Total & 326 & 100.0 \\
\hline \multirow{5}{*}{ Kind of wear } & Bicycle wear & 208 & 63.8 \\
\hline & Outdoor wear & 50 & 15.3 \\
\hline & Day wear & 34 & 10.4 \\
\hline & Training wear & 34 & 10.4 \\
\hline & Total & 326 & 100.0 \\
\hline \multirow{3}{*}{$\begin{array}{l}\text { Experience of } \\
\text { purchase }\end{array}$} & Yes & 250 & 76.7 \\
\hline & No & 76 & 23.3 \\
\hline & Total & 326 & 100.0 \\
\hline \multirow{5}{*}{$\begin{array}{l}\text { Frequency of } \\
\text { wearing } \\
\text { bicycle wear }\end{array}$} & Always wearing & 199 & 79.0 \\
\hline & Meeting or lesson & 37 & 14.7 \\
\hline & Arrival and departure & 5 & 2.0 \\
\hline & Not wearing & 11 & 4.4 \\
\hline & Total & 252 & 100.0 \\
\hline \multirow{8}{*}{$\begin{array}{c}\text { Place of purchased } \\
\text { bicycle wear }\end{array}$} & Internet Site & 106 & 37.5 \\
\hline & Bicycle wear store & 148 & 52.3 \\
\hline & Overseas purchase & 14 & 4.9 \\
\hline & Department & 2 & 0.7 \\
\hline & Discount store & 4 & 1.4 \\
\hline & Outdoor wear Store & 4 & 1.4 \\
\hline & Others & 5 & 1.8 \\
\hline & Total(Multiple response) & 283 & 100.0 \\
\hline
\end{tabular}

\section{3. 자전거 의류 구입 시 고려 사항}

자전거 의류 구입 시 고려 사항 21 문항에 대한 하위차원을 알아보기 위하여, 주성분분석과 varimax 회전에 의한 주성분 분석을 이용하여 고유값 1 이상을 기준으로 탐색적 요인분석을 실시하였다. 요인분석 결과, 문항의 내용 검토 후 요인과 문항 내용이 부합되지 않고 신뢰도를 저해하는 2 개의 문항을 제거 하여 19 문항에 대한 2 차 요인분석을 실시하였다. 총 4 개의 요 인이 추출되었으며, 요인 1은 ‘통풍기능이 중요하다', ‘땀의 흡

Table 3. One-way ANOVA of standards of selection when purchasing wears $(N=326)$

\begin{tabular}{|c|c|c|c|c|c|c|}
\hline \multirow{2}{*}{ Category } & $20 \mathrm{~s}$ & $30 \mathrm{~s}$ & $40 \mathrm{~s}$ & $50 \mathrm{~s}$ & over $60 \mathrm{~s}$ & \multirow{2}{*}{ F-value } \\
\hline & $\mathrm{M}(\mathrm{SD})$ & $\mathrm{M}(\mathrm{SD})$ & $\mathrm{M}(\mathrm{SD})$ & $\mathrm{M}(\mathrm{SD})$ & $\mathrm{M}(\mathrm{SD})$ & \\
\hline Design & $8.47(1.91) a$ & $8.45(1.71) \mathrm{a}$ & $7.53(2.05) b$ & $7.55(2.22) b$ & $7.14(2.22) b$ & $5.288 * * *$ \\
\hline Price & $8.39(1.89) \mathrm{a}$ & 7.88(1.96)a & $6.88(2.40) \mathrm{b}$ & $6.61(2.98) b$ & $6.49(2.93) b$ & $7.985 * * *$ \\
\hline Fabric & $8.38(1.72) \mathrm{a}$ & $7.90(1.86) \mathrm{ab}$ & 7.76(1.78)abc & $7.49(2.27) b c$ & $7.03(2.63) \mathrm{c}$ & $3.358 *$ \\
\hline Color & $8.58(1.72) a$ & $7.96(1.85) \mathrm{ab}$ & $7.78(1.81) b$ & $7.41(2.25) b$ & $7.40(2.35) b$ & $4.172 * *$ \\
\hline Size & $8.68(1.86) \mathrm{a}$ & 8.33(1.73)a & 7.94(1.99)ab & $8.02(2.44) \mathrm{a}$ & $7.17(2.58) b$ & $3.428 * *$ \\
\hline Function & 8.43(1.78)a & $8.55(1.68) \mathrm{a}$ & $8.08(1.91) \mathrm{a}$ & $7.96(2.36) \mathrm{a}$ & 7.94(2.32)a & 1.312 \\
\hline Brand & $6.55(2.47) \mathrm{a}$ & $5.90(2.38) \mathrm{a}$ & $6.55(1.81) \mathrm{a}$ & $5.96(2.39) \mathrm{a}$ & $6.23(2.28) \mathrm{a}$ & 1.260 \\
\hline
\end{tabular}

$* p<.05, * * p<.01, * * * p<.001$

Duncan's multiple range test: $\mathrm{a}>\mathrm{b}>\mathrm{c}$ 
Table 4. Factor analysis of considerations for purchase of bicycle wear

\begin{tabular}{|c|c|c|c|c|c|}
\hline Factor & Item & Factor loading & Eigen value & $\begin{array}{c}\% \text { of Variance explained } \\
\text { (Accumulated) }\end{array}$ & Cronbach's $\alpha$ \\
\hline \multirow{8}{*}{$\begin{array}{c}\text { Factor1 } \\
\text { Functionality }\end{array}$} & Breathable fabric is essential. & .816 & \multirow{8}{*}{6.050} & \multirow{8}{*}{$\begin{array}{c}31.843 \\
(31.843)\end{array}$} & \multirow{8}{*}{.879} \\
\hline & It has to absorb sweat well. & .814 & & & \\
\hline & It has to be breathable and waterproof. & .788 & & & \\
\hline & It has to have good texture. & .723 & & & \\
\hline & It has to be lightweight. & .663 & & & \\
\hline & It has to be insulating ability. & .653 & & & \\
\hline & It has to be elastic. & .651 & & & \\
\hline & It has to be durable to be worn for long. & .557 & & & \\
\hline \multirow{3}{*}{$\begin{array}{l}\text { Factor2 } \\
\text { Fashion }\end{array}$} & People prefer tight clothing. & .803 & \multirow{3}{*}{2.344} & \multirow{3}{*}{$\begin{array}{c}12.337 \\
(44.180)\end{array}$} & \multirow{3}{*}{.752} \\
\hline & People prefer slim fit styles. & .764 & & & \\
\hline & It has to be trendy. & .627 & & & \\
\hline \multirow{4}{*}{$\begin{array}{c}\text { Factor3 } \\
\text { Serviceability }\end{array}$} & It should be easy to put it on and take it off. & .830 & \multirow{4}{*}{1.484} & \multirow{4}{*}{$\begin{array}{c}7.809 \\
(51.989)\end{array}$} & \multirow{4}{*}{.722} \\
\hline & People prefer clothing which is easy to wash and keep. & .755 & & & \\
\hline & It is essential that people can wear it at all times. & .577 & & & \\
\hline & It is important to have pockets to put in belongings. & .515 & & & \\
\hline \multirow{4}{*}{$\begin{array}{l}\text { Factor4 } \\
\text { Color }\end{array}$} & People prefer soft colors like pastel colors. & .752 & \multirow{4}{*}{1.081} & \multirow{4}{*}{$\begin{array}{c}5.689 \\
(57.678)\end{array}$} & \multirow{4}{*}{.585} \\
\hline & $\begin{array}{l}\text { People prefer outstanding and colorful colors such as } \\
\text { primary colors. }\end{array}$ & .659 & & & \\
\hline & Patterns(Textiles) are important. & .598 & & & \\
\hline & People prefer achromatic colors. & .470 & & & \\
\hline
\end{tabular}

수가 잘 되어야 한다, 등 의복의 기능적인 부분에 대한 문항으 로 구성되어, 기능성 요인으로 명명하였고 총 8 문항으로 구성 되었다. 요인 2는 ‘몸에 딱 달라붙는 스타일을 선호한다', '최신 유행하는 스타일이어야 한다, 등 스타일과 유행에 관련된 문항 으로 구성되어 패션성요인으로 명명하였다. 요인 3은 입고 벗 기 편해야 한다', '세탁 및 관리가 용이한 것을 선호한다' 등 의복의 관리와 착용의 편리에 대한 문항으로 구성되어, 편리성 요인으로 명명하였다. 요인 4는 '파스텔 계열의 부드러운 색상 을 선호한다', '패턴(프린트/무늬)이 중요하다' 등 의복의 색상 과 문양에 대한 문항으로 구성되어, 색채요인으로 명명하였으 며 총 4문항으로 구성되어 있다. 총 설명변량은 $57.68 \%$ 를 나 타냈으며 측정문항의 신뢰도를 검증하기 위해 크론바하 알파 (Cronbach's $\alpha$ )를 산출하였다. 신뢰도 분석결과 신뢰도 계수는 0.879 0.585로 나타났다(Table 4). 기능성요인이 총 설명변량 중 $31.84 \%$ 로 가장 높은 비중을 차지하였으며, 다음으로 패션 성요인이 $12.34 \%$, 편리성요인이 $7.81 \%$, 색채요인이 $5.69 \%$ 순 으로 나타났다. 이는 자전거를 타고 달릴 때, 땀을 많이 흘리

Table 5. Correlation analysis of factors

\begin{tabular}{cccc}
\hline & Functionality & Fashion & Serviceability \\
\hline Fashion & $.431^{* * *}$ & & \\
Serviceability & $.433 * * *$ & $.366^{* * *}$ & \\
Color & $.195 * * *$ & $.404 * * *$ & $.450 * * *$ \\
\hline$* * p<.001$ & &
\end{tabular}

기 때문에 통풍기능, 흡수, 투습방수 등의 기능이 강조된 소재 를 사용과 같은 요인이 자전거 의류 구입 시 가장 큰 영향을 미치는 것으로 판단된다.

자전거 의류 구입 시 고려사항의 하위요인인 기능성요인, 패 션성요인, 편리성요인, 색채요인 간의 상관관계를 알아보기 위 하여 Pearson의 적률상관계수를 산출하여 상관관계분석을 실시 하였고, 그 결과는 다음과 같다(Table 5). 기능성요인, 패션성요 인, 편리성요인, 색채요인 모두 유의한 상관관계를 나타내었으 며, 서로 정(+)적인 관계에 있었다.

\section{4. 자전거 주행 시 착용한 의복의 불편사항}

자전거 주행 시 착용한 의복의 불편사항을 5 점 척도('전혀 그렇지 않다' 1점, '매우 그렇다' 5점)로 조사한 결과는 Table 6, Table 7과 같다. 상의에서는 '허리부위가 당겨 올라간다'는 의견에 '그렇다'가 105 명(32.2\%), '매우 그렇다'가 42명(12.9\%) 로 조사대상자의 대부분이 자전거 주행 시 자전거 의류를 착용 하고 있음에도 불구하고 허리 부위의 불편함은 여전히 존재하 는 것으로 나타났다. 그러므로 자전거 의류의 상의 패턴 설계 시 뒤를 더 길게 설정하고, 상의가 당겨 올라가지 않도록 밑단 처리를 해야 할 것으로 사료된다. '소지품 수납이 불편하다'는 질문에 ‘그렇다'가 94명(28.8\%), '매우 그렇다'가 45명(13.8\%) 로 나타나 상의 주머니 설계 시 자전거 주행에 방해가 되지 않 으면서 주행 시 필요한 소지품을 수납할 수 있는 공간에 대한 고려가 이루어져야 할 것이다. '여밈지퍼의 끝부분이 턱에 닿 
Table 6. The inconvenient details in bicycle wear(Tops) $(\mathrm{N}=326)$

\begin{tabular}{|c|c|c|c|c|c|c|}
\hline \multirow{2}{*}{ Item } & \multirow{2}{*}{$\begin{array}{c}\text { Disagree } \\
\mathrm{N}(\%) \\
\end{array}$} & \multicolumn{3}{|c|}{ Neutral } & \multirow{2}{*}{$\begin{array}{l}\text { Agree } \\
\mathrm{N}(\%) \\
\end{array}$} & \multirow{2}{*}{$\begin{array}{l}\text { Mean } \\
(\mathrm{SD})\end{array}$} \\
\hline & & $\mathrm{N}(\%)$ & $\mathrm{N}(\%)$ & $\mathrm{N}(\%)$ & & \\
\hline The back part feels tight. & $37(11.3)$ & $39(12.0)$ & 157(48.2) & $65(19.9)$ & $28(8.6)$ & $3.02(1.06)$ \\
\hline The waist part pulls up. & $23(7.1)$ & $35(10.7)$ & $121(37.1)$ & $105(32.2)$ & $42(12.9)$ & $3.33(1.06)$ \\
\hline The armpit part is tight. & $33(10.1)$ & $56(17.2)$ & 152(46.6) & $72(22.1)$ & $13(4.0)$ & $2.93(0.98)$ \\
\hline Wide sleeves are cumbersome. & $43(13.2)$ & $58(17.8)$ & $124(38.0)$ & $67(20.6)$ & $34(10.4)$ & $2.97(1.15)$ \\
\hline Sleeves pull up. & $45(13.8)$ & $57(17.5)$ & $115(35.3)$ & $89(27.3)$ & $20(6.1)$ & $2.94(1.12)$ \\
\hline $\begin{array}{l}\text { When the back part balloons out with the wind, } \\
\text { it is uncomfortable. }\end{array}$ & $39(12.0)$ & $50(15.3)$ & $138(42.3)$ & $69(21.2)$ & $30(9.2)$ & $3.00(1.10)$ \\
\hline It is inconvenient to put in belongings. & $31(9.5)$ & $51(15.6)$ & $105(32.2)$ & $94(28.8)$ & $45(13.8)$ & $3.22(1.15)$ \\
\hline The front neck pulls up. & $32(9.8)$ & $56(17.2)$ & $135(41.4)$ & $74(22.7)$ & $29(8.9)$ & $3.04(1.07)$ \\
\hline The top part of the zipper touches the chin, so it hurts. & $40(12.3)$ & $53(16.3)$ & $112(34.4)$ & $81(24.8)$ & $40(12.3)$ & $3.09(1.18)$ \\
\hline
\end{tabular}

Shading indicates a higher percentage.

Table 7. The inconvenient details in bicycle wear(Pants) $(\mathrm{N}=326)$

\begin{tabular}{|c|c|c|c|c|c|c|}
\hline \multirow{2}{*}{ Item } & \multirow{2}{*}{$\begin{array}{c}\text { Disagree } \\
\mathrm{N}(\%)\end{array}$} & \multicolumn{3}{|c|}{ Neutral } & \multirow{2}{*}{$\begin{array}{l}\text { Agree } \\
\mathrm{N}(\%)\end{array}$} & \multirow{2}{*}{$\begin{array}{l}\text { Mean } \\
(\mathrm{SD})\end{array}$} \\
\hline & & $\mathrm{N}(\%)$ & $\mathrm{N}(\%)$ & $\mathrm{N}(\%)$ & & \\
\hline The abdominal part feels pressured. & $53(16.3)$ & $66(20.2)$ & $106(32.5)$ & $77(23.6)$ & $24(7.4)$ & $2.86(1.16)$ \\
\hline The hip part feels pressured. & $47(14.4)$ & $58(17.8)$ & $138(42.3)$ & $59(18.1)$ & $24(7.4)$ & $2.86(1.10)$ \\
\hline In case of a long ride, the bottom is sore. & $22(6.7)$ & $53(16.3)$ & $97(29.8)$ & $84(25.8)$ & $70(21.5)$ & $3.39(1.18)$ \\
\hline It is uncomfortable when the pants legs get folded. & $38(11.7)$ & $67(20.6)$ & $114(35.0)$ & $65(19.9)$ & $42(12.9)$ & $3.02(1.17)$ \\
\hline The knee part is uncomfortable and tight. & $40(12.3)$ & $60(18.4)$ & $111(34.0)$ & $77(23.6)$ & $38(11.7)$ & $3.04(1.17)$ \\
\hline The back waistline comes down. & $33(10.1)$ & $55(16.9)$ & $117(35.9)$ & $85(26.1)$ & $36(11.0)$ & $3.11(1.12)$ \\
\hline It is inconvenient to put in belongings. & $27(8.3)$ & $38(11.7)$ & $119(36.5)$ & $96(29.4)$ & $46(14.1)$ & $3.29(1.10)$ \\
\hline The wide pants legs are cumbersome. & $49(15.0)$ & 67(20.6) & 104(31.9) & $61(18.7)$ & $45(13.8)$ & $2.96(1.24)$ \\
\hline The leg hems pull up. & $53(16.3)$ & $65(19.9)$ & $106(32.5)$ & $65(19.9)$ & $37(11.3)$ & $2.90(1.22)$ \\
\hline
\end{tabular}

Shading indicates a higher percentage.

아 아프다'는 의견에 ‘그렇다'가 81 명(24.8\%), '매우 그렇다'가 40명(12.3\%)로 나타났다. 이는 자전거 의류의 경우 목 부분이 스탠드칼라 형태로 디자인된 것이 대부분으로, 지퍼를 끝까지 올렸을 때, 딱딱한 지퍼의 끝부분이 턱에 닿아 마찰을 일으켜 불편한 것으로 생각된다. 따라서 자전거 의류의 상의에 사용되 는 지퍼는 소재를 고려하여 선정해야 할 것이다. '목 앞이 당 겨 올라간다'는 질문에 '그렇다'가 74 명(22.7\%), '매우 그렇다' 가 29 명 $(8.9 \%)$ 로 나타났으며, '등 부위가 당긴다'는 의견이 '그 렇다'가 65명(19.9\%), '매우 그렇다'가 28명 $(8.6 \%)$ 로 나타나 자 전거 의류의 소재 선택 시 스트레치성이 필요하며, 주행 중 상 체를 앞으로 숙이는 동작을 고려한 패턴 설계와 여유분 설정이 필요할 것으로 사료된다.

하의에서는 '오래 타면 밑이 배긴다'는 의견에 '그렇다'가 84 명 $(25.8 \%)$, '매우 그렇다'가 70명(21.5\%)로 가장 높게 나타났 다. 자전거 의류의 하의에는 패드가 삽입되어 있거나 패드를 따 로 착용하는 경우가 대부분임에도 불구하고 밑이 배긴다는 의 견이 하의의 불편사항 중 가장 높게 나타났다는 것은 기능성 자전거 의류 설계 시 보완되어야 할 중요한 부분임을 알 수 있었다. 다음으로 ‘소지품 수납이 불편하다’라는 질문에 '그렇 다'가 96명(29.4\%), '매우 그렇다’가 46명(14.1\%)로 나타나 상
의와 하의에서 모두 소지품 수납과 관련된 불편함을 느끼고 있 으므로, 주행에 방해가 되지 않는 적절한 수납공간 마련이 필 요할 것으로 판단된다. '뒤허리선이 내려온다'는 의견에 '그렇 다'가 85명(26.1\%), '매우 그렇다'가 36명(11.0\%)로 나타나 앉 는 자세를 고려한 패턴설계와 신축성이 부여된 소재의 사용, 허 리선이 내려오지 않도록 고정하는 장치가 필요할 것으로 사료 된다. '무릎부분이 불편하고 옷이 당긴다'는 질문에 '그렇다'가 77명(23.6\%), '매우 그렇다'가 38명(11.7\%)로 나타났으며, '바 지 가랑이 부위가 접혀서 불편하다'는 질문에 ‘그렇다’가 65 명 (19.9\%), '매우 그렇다'가 42명(12.9\%)로 나타났다. 이는 자전 거 주행 중 페달을 밟는 동작을 지속적으로 하기 때문에 생기 는 불편사항으로 무릎부분에 신축성 또는 인체공학적 패턴 설 계가 뒷받침 되어야 하며, 바지 가랑이부분의 치수적합성의 문 제가 해결되어야 할 것이다.

\section{5. 자전거 의류에 필요한 기능}

자전거 의류에 필요한 기능을 조사한 결과는 Table 8 과 같 다. '야간 주행 시 이용자 보호를 위한 발광 기능이 있었으면 좋겠다'는 응답이 전체의 289명(88.7\%)을 차지하여 가장 많았 다. 따라서 자전거 의류 제작 시 야간 주행 중 앞서 달려가는 
Table 8. Functions required for bicycle wear $(\mathrm{N}=326)$

\begin{tabular}{|c|c|c|}
\hline Items & $\mathrm{N}$ & $\%$ \\
\hline It will be better to have a heating function to keep warm. & 239 & 73.3 \\
\hline It will be better to adjust insulation with injected air. & 211 & 64.7 \\
\hline When a cell phone rings or receives messages, it will be better to have an alarm function with vibration. & 212 & 65.0 \\
\hline In case of accidents, it will be better to have a function to cushion the impact. & 277 & 85.0 \\
\hline It will be better to have GPS functions to find directions or friends. & 203 & 62.3 \\
\hline It will be better to block fine dust. & 257 & 78.8 \\
\hline It will be better to have a function to inform weather or temperature in real time. & 163 & 50.0 \\
\hline It will be better to have a small camera on the jacket to take pictures while riding a bicycle. & 200 & 61.3 \\
\hline It will be better to have a MP3 player to listen to music by plugging in a flash drive. & 206 & 63.2 \\
\hline It will be better to have a function to pull up leg hems. & 166 & 50.9 \\
\hline It will be better to have a luminous function to protect bicycle riders at night. & 289 & 88.7 \\
\hline It will be better to have a function to change colors by temperature in an aspect of design. & 179 & 54.9 \\
\hline It will be better to have a function to check consumed energy. & 190 & 58.3 \\
\hline It will be better to have a mask attached to a jacket. & 169 & 51.8 \\
\hline It will be better to have a gloves attached to a jacket. & 145 & 44.5 \\
\hline
\end{tabular}

Shading indicates a higher percentage.

Table 9. Intention to purchase of functional bicycle wear $(\mathrm{N}=326)$

\begin{tabular}{|c|c|c|c|c|c|}
\hline Gender $\cdot$ Age & Intention to purchase & Yes & No & Total & $\chi^{2}$ \\
\hline \multirow{3}{*}{ Gender } & Male & $155(47.5)$ & $53(16.3)$ & $208(63.8)$ & \multirow{3}{*}{1.511} \\
\hline & Female & $95(29.1)$ & $23(7.1)$ & $118(36.2)$ & \\
\hline & Total & $250(76.7)$ & $76(23.3)$ & $326(100.0)$ & \\
\hline \multirow{6}{*}{ Years } & $20 \mathrm{~s}$ & $51(15.6)$ & $26(8.0)$ & $77(23.6)$ & \multirow{6}{*}{$26.748 * * *$} \\
\hline & $30 \mathrm{~s}$ & $55(16.9)$ & $25(7.7)$ & $80(24.5)$ & \\
\hline & $40 \mathrm{~s}$ & $45^{\mathrm{a}}\left(13.8^{\mathrm{b}}\right) 37.6^{\mathrm{c}}$ & $4(1.2)$ & $49(15.0)$ & \\
\hline & $50 \mathrm{~s}$ & $77^{\mathrm{a}}\left(23.6^{\mathrm{b}}\right) 65.2^{\mathrm{c}}$ & $8(2.5)$ & $85(26.1)$ & \\
\hline & $60 \mathrm{~s}$ & $22(6.7)$ & $13(4.0)$ & $35(10.7)$ & \\
\hline & Total & $250(76.7)$ & $76(23.3)$ & $326(100.0)$ & \\
\hline
\end{tabular}

${ }^{\mathrm{a}}$ : Observed N, ${ }^{\mathrm{b}}$ : Percent, ${ }^{\mathrm{c}}$ : Expected N

$* * * p<.001$

자전거와의 거리나 반대편에서 달려오는 자전거를 확인할 수 있도록 발광 기능이 있는 원단을 사용하거나, 발광 기능을 탈 부착할 수 있도록 제작되어야 할 것이다. 다음으로 '사고발생 시 충격완화를 위한 기능이 있었으면 좋겠다'는 응답이 277명 (85.0\%)로 나타나, 헬멧을 비롯한 보호 장비를 착용하는 것 외 에 자전거 의류 자체에 충격완화를 위한 기능이 필요한 것으로 보인다. 따라서 사고발생 시 부상을 입는 부위 및 경로를 파악 하고, 자전거 의류 설계 시 부상을 최소화할 수 있도록 충격완 화섬유를 사용하거나 주행에 방해가 되지 않는 패드 디자인을 고려해야 할 것이다. '미세먼지를 차단할 수 있는 기능이 있었 으면 좋겠다는 응답이 257 명 $(78.8 \%)$ 으로 나타나, 도심에서 자 전거를 주행하는 경우 미세먼지로 인한 불편과 호흡기 관련 질 환에 대한 두려움을 파악할 수 있었다. 따라서 이를 예방할 수 있도록 미세먼지 차단 기능이 있는 마스크 제작이 필요할 것으 로 사료된다. '몸을 따뜻하게 해주는 발열 기능이 있었으면 좋
겠다'는 응답이 239 명 $(73.3 \%)$ 로 나타나 예전엔 자전거 주행을 날씨가 따뜻한 봄 - 가을철에만 즐기는 운동으로 여겼다면, 지 금은 계절과 날씨와 상관없이 자전거 라이딩을 즐기는 것으로 파악된다. 따라서 기온이 낮은 겨울철에도 자전거 주행에 무리 가 없도록 발열 기능이 있는 의류를 자전거 의류 안에 입을 수 있도록 제작하거나, 발열 기능을 조절할 수 있는 자전거 의 류를 제작할 필요가 있다고 생각된다.

스마트한 기능이 있는 자전거 의류가 판매된다면 구매할 의 도가 있는지 질문한 결과, '구매하겠다'는 의견이 전체 응답자 중 250 명 $(76.7 \%)$ 으로 매우 높게 나타나 기능성 자전거 의류에 대한 소비자의 수용 가능성을 엿볼 수 있었다. 또한, 기능성 자 전거 의류에 대한 구매 의도가 성별과 연령에 따라 차이가 있 는지 알아보기 위해 교차분석을 실시한 결과, 성별에 따라서는 유의한 차이가 나지 않았으나, 연령에 따라서는 유의한 차이가 나타났다(Table 9). 40대는 45명(13.8\%)이 ‘구매하겠다’라고 응 
답하였으며, 50대는 77 명 $(23.6 \%$ )이 ‘구매하겠다'라고 응답하여 기대빈도보다 관측빈도가 높게 나타나 장년층에서 기능성 자전 거 의류에 대한 구매 의사가 높은 것으로 나타났다. 이는 Table 3 의 결과로 미루어 보아, 20 대와 30 대는 디자인과 가격에 민감 하게 반응하기 때문에 기능성 자전거 의류에 대한 구매 의도는 기대빈도보다 관측빈도가 낮게 나타난 것으로 사료된다.

\section{5. 결 론}

현대인들의 소득수준 향상과 근로시간 단축에 따른 여가시 간의 증가 및 여가활동의 다양화는 웰빙 문화 확산과 함께 건 강에 대한 관심의 증가로 이어져 자전거 의류 시장은 지속적으 로 확대되고 있다. 이에 본 연구에서는 자전거 의류의 착용실 태 조사를 통해 소비자의 성향을 파악하고, 자전거 의류에 대 한 다양한 니즈를 분석하고자 하였다.

자전거 이용자들의 자전거 의류 착용실태를 조사한 결과는 다음과 같다.

첫째, 본 연구의 조사 대상자들은 남성이 많은 수를 차지하 였으며, 청-장년층이 주를 이루었다. 건강에 대한 관심으로 자 전거를 즐기는 연령층이 다양하게 나타났으며, 정기적으로 자 전거를 이용하고 있었다. 자전거를 이용하는 주된 목적은 여가 와 건강을 중시하는 웰빙 트렌드의 영향으로 동호회 활동과 운 동용, 여가선용 등으로 나타났다.

둘째, 자전거 주행 시에는 주로 자전거 전문 의류를 착용하 고, 자전거 의류를 전문으로 생산하는 브랜드를 알고 있었다. 자전거의류전문매장을 통해 자전거 전문 의류를 구매한 경험이 있는 응답자가 다수로 나타나 자전거 전문 의류에 대한 인식이 매우 높은 것을 알 수 있었으며, 자전거 주행 시 자전거 의류 의 착용빈도가 높은 것으로 나타났다. 자전거 의류 구입 시 기 능성과 사이즈 및 디자인이 선택의 기준이 되며, 20 대와 30 대 는 디자인과 가격을 중시하는 것으로 나타났다. 이에 자전거 의 류 제작 시 착의만족도를 높일 수 있는 패턴설계 및 기능성 소재의 사용이 필요할 것으로 사료된다.

셋째, 자전거 의류 구입 시 고려 사항에 대해서는 기능성, 패션성, 편리성, 색채성 요인으로 나타났고, 통풍기능, 땀 흡수 기능, 투습방수 기능 등 소재의 기능성이 자전거 의류 구입 시 가장 중요한 항목임을 알 수 있었다. 이와 같은 기능성 소재의 사용은 일반인에게는 자전거 주행 중 쾌적감을 높여주며, 자전 거 주행을 직업으로 하는 전문선수들에게는 기록갱신과 직접적 으로 연결되는 요인이 될 것이다.

넷째, 자전거 주행 시 착용한 의복의 불편사항을 조사한 결 과, 상의에서는 허리부위가 당겨 올라가서 불편하다는 의견이 가장 많았으며, 하의에서는 오래 타면 밑이 배겨서 불편하다는 의견이 가장 많았다. 이에 자전거 주행 자세를 고려한 패턴설 계와 함께 기능성 소재의 사용이 필요하다. 그리고 상 - 하의 공통적으로 소지품 수납이 불편하다는 의견이 높게 나타나 자 전거 주행에 방해가 되지 않는 적절한 수납공간이 필요하다.
다섯째, 자전거 의류에 필요한 기능에 대해서는 야간 주행 시 이용자 보호를 위한 발광기능, 사고발생 시 충격완화를 위 한 기능, 미세먼지를 차단할 수 있는 기능 등 주로 안전과 관 련된 기능에 요구도가 높게 나타났다. 또한 스마트한 기능이 있 는 자전거 의류에 대한 구매의도가 40 대와 50 대에서 높게 나 타나 장년층에서 기능성 자전거 의류에 대한 구매 의사가 높은 것으로 나타났다.

따라서 추후 연구에서는 본 연구의 결과를 바탕으로 자전거 의류의 불편사항을 개선하고, 한국인의 인체치수를 고려한 인 체공학적 패턴설계와 함께 기능성 소재의 사용으로 소비자들의 다양한 요구를 반영한 기능성 자전거 의류의 개발이 이루어져 야 할 것이다. 나아가 자전거 주행 시 신체를 보호해주는 기능 과 디자인 감각이 우수한 자전거 의류의 개발은 소비자들에게 는 자전거 의류의 구매 만족도를 향상시켜주며, 의류 생산 업 체에게는 제품생산에 도움을 주어, 산업적으로 경제 효과의 상 승을 가져오게 될 것이다.

\section{감사의 글}

본 논문은 2012년도 Brain Busan 21사업에 의하여 지원되 었음.

\section{References}

'Bicycle fashion'. (2010, June 9). Hankyung.com. Retrieved April 25, 2012, from http://www.hankyung.com

'Bicycle goods'. (2011, October 25). Edaily. Retrieved January 18, 2012, from http://www.edaily.co.kr

Cho, E. H. (2012, March 30). 'Le Coq Sportif' released the cycle line. Apparelnews. Retrieved April 27, 2012, from http://www. apparelnews.co.kr

Choi, M. S. (2004). An exploratory research on pattern development of bicycle apparel for cyclists. Journal of the Korean Society of Clothing and Textiles, 28(5), 637-647.

Jeong, J. K. (2011, May 24). Attraction of bicycle. Citylife 278. Retrieved April 25, 2012, from http://www.mk.co.kr

Jeong, J. W. (2010, April 17). Diverse designs along with functions, more companies release 'bikewear'. Sports World. Retrieved April 25, 2012, from http://sportsworldisegye.com

Kim, E. K. (2010). A study of the current state of cyclist wear. Journal of the Korean Society of Costume, 60(5), 88-105.

Kim, H. J., \& Park, C. C. (2011). Domestic design patent analysis of functional clothing. Journal of the Korean Society for Clothing Industry, 13(1), 1-6.

Kim, W., Kim, S. Y., Lee, J. Y., Kim, S. K., \& Lee, K. Y. (2009). Comparison of commuter's $\mathrm{PM}_{10}$ exposure using different transportation modes of bus and bicycle. Journal of Environmental Health Sciences, 35(6), 480-486.

Kim, Y. R. (2012, April 19). Bicycle market. Asia Business Daily. Retrieved April 25, 2012, from http:/www.asiae.co.kr

'Lafuma bicycles'. (2010, April 19). Fashion Journal. Retrieved April 
25, 2012, from http://okfashion.co.kr

Lee. Y. J., \& Suh, M. A. (2008). A study on wearing satisfaction of cycle wear. The Research Journal of the Costume Culture, 16(2), 219-234.

Lim, S. Y. (2012, April 19). Trading activity surged in the bicycle stock market. Money Today. Retrieved April 25, 2012, from http:/ /news.mt.co.kr

'Outdoor market'. (2011, July 6). Yonhapnews. Retrieved April 25, 2012, from http://www.yonhapnews.co.kr

Park, D. H. (2012, March 16). 'Citizen patrol' helps bicycle riding in downtown. Korea.kr. Retrieved March 21, 2012, from http:// www.korea.kr

Ryu, S. A. (2012, April 5). Bicycle popularity upper 50\% sale. News Tomato. Retrieved April 25, 2012, from http://www.hankyung.com Shin, K. H. (2011, December 28). Construction corporation 'Bicycle marketing'. The Seoul Finance. Retrieved January 18, 2012, from http://www.seoulfn.com

(Received 24 January 2013; 1st Revised 20 February 2013; 2nd Revised 12 March 2013; Accepted 1 April 2013)

Copyright (C) The Society of Fashion and Textile Industry. 2013. This is an open access article distributed under the terms and conditions of the Creative Commons Attribution Non-Commercial license (http://creativecommons.org/licenses/by-nc/3.0/), which permits unrestricted non-commercial use, distribution, and reproduction in any medium, provided the original work is properly cited. 